\title{
KEBERHASILAN PESANTREN SALAFIYAH DALAM PELAKSANAAN PENDIDIKAN DASAR
}

\author{
Dr. Hj. Munawiroh, M.Pd
}

Pondok Pesantren Salafiyah adalah salah satu jenis pendidikan yang banyak diselenggarakan oleh masyarakat, terutama pada kalangan masyarakat santri tradisional, dimana santri hanya diajarkan pelajaran agama yang bersumber dari kitab-kitab klasik berbahasa Arab (kitab kuning). Sistem pembelajaran pada pondok pesantren salafiyah berbeda dengan sistem pembelajaran pada sekolah atau madrasah. Perbedaan tersebut memunculkan beberapa permasalahan, diantara permasalahannya adalah sebagai berikut:

1. Pondok pesantren tidak memiliki aturan dan jenjang Pendidikan seperti aturan dan jenjang Pendidikan pada sekolah atau madrasah. Jenjang Pendidikan pada pondok pesantren adalah kitab yang diajarkan oleh kyai, jika dianggap telah selesai mempelajari kitab tertentu maka dianggap telah selesai pendidikannya, disamping itu kitab yang diajarkan pada tiap-tiap pondok pesantren juga tidak sama, sesuai dengan penguasaan keilmuan sang kyai, makanya setiap pondok pesantren memiliki kekhasan keilmuan sendiri-sendiri yang sering kali berbeda-beda. Begitu pula usia santri, tidak ada persyaratan tertentu terkait dengan usia berapa seorang santri dapat mengikuti Pendidikan di pondok pesantren, ada yang masih belia, remaja, atau bahkan ada yang sudah berumur atau dewasa dan sudah tua. Santri dinyatakan telah menyelesaikan belajarnya di pondok pesantren apabila sang kyai telah menyatakan cukup atau santri itu sendiri yang merasa telah selesai. Tidak ada lembar ijazah yang diperoleh oleh santri, meskipun masa belajarnya mungkin baru setahun, beberapa tahun atau telah berpuluh tahun dan telah menguasai berbagai ilmu pengetahuan agama serta berbagai kitab yang telah diajarkan oleh kyai. Pengakuan kesantriannya adalah Ketika santri tersebut berkiprah di masyarakat, kemampuan dan kehebatannya akan dinilai secara langsung oleh masyarakat yang dapat menerimanya. Mungkin santri tersebut bisa menjadi tokoh, pemimpin, ulama, mubaligh, guru, ustadz, atau bahkan pemimpin negara.

2. Pendidikan yang diselenggarakan oleh sekolah atau madrasah mensyaratkan siswanya mempelajari mata pelajaran tertentu, yakni mata pelajaran yang diujikan atau disyaratkan sebagai mata pelajaran yang harus menjadi kemampuan dasar Pendidikan, pada jenjang dasar yang harus dipelajari oleh setiap siswa minimal 3 (tiga) mata pelajaran, yakni Bahasa Indonesia, PPKN, dan Matematika. Ketiga mata pelajaran ini adalah mata pelajaran yang telah ditetapkan oleh undang-undang sebagai mata pelajaran yang harus diujikan dalam ujian nasional dan dimasukkan sebagai Nilai Evaluasi Murni (NEM). Sementara pada pada pondok pesantren salafiyah tidak mengajarkan ketiga 
mata pelajaran tersebut, sehingga santri tidak dapat mengikuti ujian dan tidak mendapatkan nilai ketiga mata pelajaran yang diwajibkan tersebut.

3. Dari sedikitnya dua permasalahan tersebut diatas dapat dipahami bahwa santri pada pondok pesantren salafiyah tidak memiliki legitimasi atas pendidikannya yang telah dijalankannya di pondok pesantren salafiyah sebagai siswa, dan santri pada pondok pesantren salafiyah juga tidak memiliki hubungan atau konektivitas dengan sekolah atau madrasah, karena berada pada dua jenis Pendidikan yang sangat berbeda karakteristik dan regulasinya. Dari hal seperti ini maka permasalahan yang timbul adalah diantaranya sebagai berikut:

a. Santri pondok pesantren salafiyah tidak memiliki ijazah formal, tidak memiliki jenjang Pendidikan yang terstandar, usia belajarnya pun sangat bervariasi. Berbeda dengan Pendidikan formal pada sekolah atau madrasah, yaitu memiliki jenjang yang terstandar, memiliki ijazah, dan usianya dibatasi dengan usia minimal dan maksimal dalam mengikuti Pendidikan pada tiap jenjang.

b. Dengan tidak memilikinya ijazah atau penjenjangan seperti yang ada pada jenjang Pendidikan formal maka santri pondok pesantren salafiyah tidak memiliki legalitas (ijazah) seperti yang dimiliki oleh sekolah atau madrasah, sehingga seringkali tidak dapat memenuhi persyaratan formal baik dalam bidang pekerjaan formal maupun Pendidikan formal yang sering kali mensyaratkan ijazah sebagai bukti telah menyelesaikan jenjang Pendidikan tertentu.

c. Pemerintah memiliki kesulitan dalam mengelompokkan santri pondok pesantren salafiyah kedalam jenjang Pendidikan dasar, menengah, atau Pendidikan tinggi. Sehingga dalam melakukan penghitungan dan manajemen pembiayaan Pendidikan yang dikelompokkan kedalam Pendidikan dasar, menengah, dan tinggi, pondok pesantren salafiyah tidak dapat diidentifikasi atau dikelompokkan kedalam jenjang Pendidikan yang mana? Dasar, menengah, ataukah tinggi. Sehingga alokasi anggaran Pendidikan pada pondok pesantren salafiyah dapat dikelompokkan sesuai dengan jenjangnya.

Untuk menyelesaikan permasalahn tersebut, pemerintah memberikan solusi pada pondok pesantren salafiyah, diantaranya adalah sebagai berikut:

1. Menyelenggarakan program wajib belajar Pendidikan dasar pada pondok pesantren, yaitu dengan memberikan kesempatan bagi pondok pesantren salafiyah yang akan menyelenggarakan yang dikelompokkan kedalam (a) tingkat Ula (setara SD/MI atau Paket A), (b) Pendidikan dasar tingkat Wustha (setara SMP/MTs atau Paket B).

2. Adapun penyelenggaraan program Pendidikan kesetaraan pondok pesantren salafiyah sebagaimana tersebut diatas adalah dengan memberikan mata pelajaran tambahan kepada santri sesuai dengan persyaratan yang ditetapkan, yaitu untuk mengikuti program Pendidikan dasar PPS Ula, dan Wustha, wajib 
mengikuti ujian mata pelajaran umum, yaitu Bahasa Indonesia, PPKN, dan Matematika, IPA, dan IPS.

3. Santri pada pondok pesantren salafiyah dapat mengikuti ujian dan jika lulus diberikan ijazah Pendidikan Dasar PPS Ula setara dengan ijazah SD/MI, dan ijazah pendidikan Dasar PPS Wustha setara dengan ijazah SMP/MTs.

4. Pondok pesantren salafiyah penyelenggara Pendidikan Dasar memiliki hak yang sama untuk mendapatkan BOS dan PIP sebagaimana Pendidikan dasar lainnya (SD/MI dan SMP/MTs).

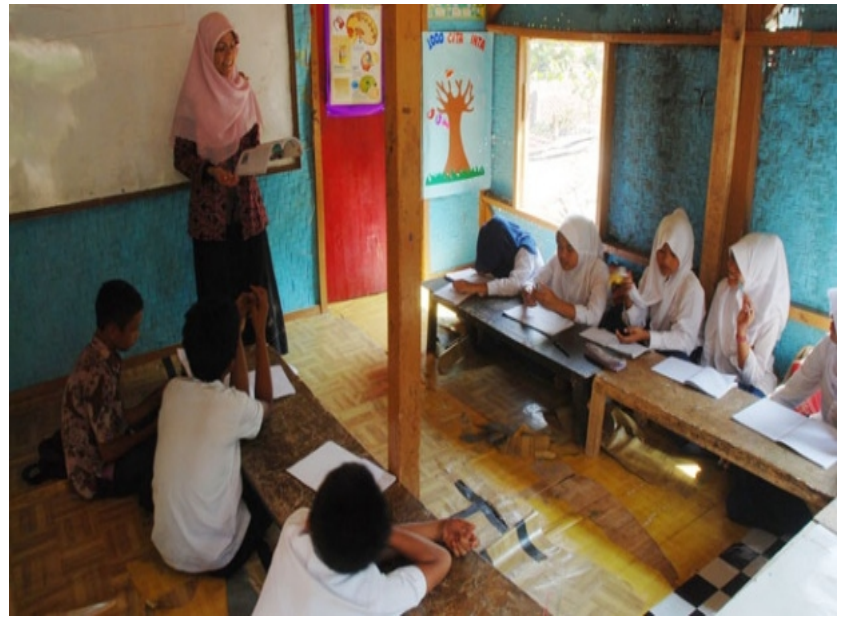

Dengan program Pendidikan Dasar pondok pesantren salafiyah maka tidak ada lagi hambatan bagi santri dalam melanjutkan Pendidikan, terutama jika santri telah menyelesaikan pendidikannya atau ingin melanjutkan pendidikan ke jenjang Pendidikan yang lebih tinggi atau ingin pindah ke jenis Pendidikan yang berbeda.

Beberapa solusi diatas disambut baik oleh pondok pesantren salafiyah dengan keikutsertaannya dalam penyelenggaraan wajardikdas. Untuk melaksanakan amanat itu, maka dalam UU No. 20 Tahun 2003 tentang Sisdiknas dinyatakan bahwa, Setiap warga negara yang berusia tujuh sampai dengan lima belas tahun wajib mengikuti pendidikan dasar. Bahkan Setiap warga negara bertanggung jawab terhadap keberlangsungan penyelenggaraan pendidikan (UU Sisdiknas, 2003). Kemudian diperjelas dan diperkuat lagi dengan dikeluarkannya Peraturan Pemerintah No. 47 tahun 2008 tentang wajib belajar sembilan tahun (PP No. 47 tahun 2008). Selanjutnya, dalam rangka meningkatkan peran pondok pesantren salafiyah sebagai lembaga pendidikan masyarakat, serta untuk membuka kesempatan bagi para santrinya yang ingin menuntut ilmu ke jenjang pendidikan yang lebih tinggi

Pondok Pesantren Salafiyah (PPS) Ula berhasil menyerap peserta didik sebanyak 69.348 dari total 26.040.407 penduduk usia 7-12 tahun. Dengan dengan demikian PPS Ula menyumbang APK sebesar $0,27 \%$ (PPS Ula) dari total APK SD sederajat sebesar 115,88\% secara nasional. Dilihat dari kesesuaian usia sekolah peserta didik PPS Ula pada tingkat SD sederajat, PPS Ula menyumbang

Pondok Pesantren Salafiyah (PPS) APM sebesar 0,11\% (PPS Ula) dari total APM SD sederajat sebesar $95,71 \%$ secara nasional. Wustha menyerap peserta didik sebanyak 39.631 (PPS Wustha) dari total 12.775 .079 penduduk usia 13-15 tahun. Dengan demikian, PPS Wustha menyumbang APK sebesar 1,09\% terhadap APK SMP sederajat sebesar 100,16\% secara nasional. Dilihat dari 
kesesuaian usia sekolah peserta didik Wustha pada tingkat SMP sederajat, PPS Wustha menyumbang APM sebesar $0,44 \%$ dari total APM SMP sederajat sebesar 78,43\% secara nasional.

Program Pendidikan kesetaraan pada pondok pesantren salafiyah ini dimulai sejak diundangkannya UU Nomor 20 Tahun 2003 tentang Sistem Pendidikan Nasional sampai dengan sekarang. Dalam perkembangannya, kini pondok pesantren telah memiliki bentuk Pendidikan formal sendiri, yakni dengan diundangkannya Pendidikan pesantren sebagai Pendidikan formal yaitu Pendidikan diniyah formal dan ma'had aly sebagai Pendidikan tinggi pondok pesantren melalui UU Nomor 18 Tahun 2019 tentang Pesantren. Semoga upaya yang telah dilakukan oleh pemerintah dapat dirasakan manfaatnya oleh masyarakat dan menjadi solusi atas permasalahan yang ada dalam dunia Pendidikan. 